\title{
Smoking prevention, cessation, and maintenance: Review for the primary care physician
}

\author{
MARK W. KETTERER PH.D. \\ ERNEST PICKERING, D.O. \\ W.W. STOEVER, D.O. \\ RICHARD A. WANSLEY, PH.D. \\ Tulsa, Oklahoma
}

Tobacco use is a major risk factor for many life-threatening and life-diminishing illnesses and a primary focus of attention for preventive medicine. Smoking typically begins in adolescence as a result of psychosocial causes, but, once established, it is maintained by both psychosocial forces and physiologic dependence. Better than 75 percent of smokers have attempted to stop at least once. Those who succeed will have tried an average of 6-7 times. The primary barrier to cessation is the discomfort of withdrawal. The primary cause of relapse following successful cessation is psychosocial stress. Adjunctive use of a nicotine-containing chewing gum with behavioral treatment enhances cessation rates but does not affect maintenance rates. Traditional behavioral treatment is still required to enhance the likelihood of cessation and minimize the likelihood of relapse. Recent research holds the hope that prevention programs directed at adolescents can significantly reduce the incidence of smoking in the general population.
In 1604, King James of England declared tobacco use a branch of drunkenness and prescribed the first known graded series of behavior-dependent contingencies for continued smoking. An initial offense resulted in excommunication from the Church, a second in public whipping, a third in cutting off the nose (based on the theory that the smell of burning tobacco was what made smoking desirable), and a fourth in death. ${ }^{1}$ To the best of our knowledge, James' behavioral program was no more, nor less, effective than current treatment. It does seem highly likely that convicted four-time losers did not continue the habit!

Tobacco use is a multibillion dollar industry in the United States. ${ }^{2,3}$ This widespread use occurs in the face of overwhelming evidence that tobacco use causes about 30 percent of all cardiovascular disease,,$^{4-20} 50$ percent of all neoplastic disease, ${ }^{21-25}$ and 90 percent of all severe chronic obstructive lung disease ${ }^{26}$ In addition, smoking has been implicated in the development of dental disease, ${ }^{27}$ osteoporosis, ${ }^{28}$ ischemic cerebrovascular events, ${ }^{29,30}$ neuropathies, ${ }^{31}$ peripheral vascular disease, ${ }^{32,33}$ gastrointestinal disorders, ${ }^{34}$ reproductive dysfunction, ${ }^{35,36}$ and premature births with related higher rates of infantile mortality or disorders. ${ }^{37-39}$ Sufficiently chronic passive or "sidestream" exposure to the smoke of others appears to increase 
heart disease, ${ }^{40,41}$ cancer, ${ }^{42,43}$ respiratory diseases ${ }^{44,45}$ psychologic disorders, ${ }^{46}$ or other illnesses in coworkers, spouses, and offspring. ${ }^{47}$ It has been estimated that 10 percent of all medical costs are attributable to smoking. ${ }^{48-50}$

Clearly, enough evidence has been marshaled to justify a major public health initiative to diminish tobacco use..$^{51-53}$ Yet, smoking prevention, cessation, and maintenance have often been viewed as activities of secondary importance by organized medicine, third-party payers, and the government alike. ${ }^{54}$ In one study, only 1 in 3 smokers reported that their physicians had ever encouraged them to stop tobacco usage. With increasing emphasis on cost containment in medicine, such preventive activities probably will assume a greater role in the professional life of the primary care physician. The present paper reviews the empiric basis for tobacco use prevention, treatment, and relapse avoidance.

\section{Diagnosis}

Tobacco users may, or may not, qualify for a formal diagnosis of Tobacco Dependence Disorder (305.1x) under the DSM III nosologic criteria. ${ }^{55}$ The health risks are probably greater for patients who are dependent than for those who are merely users, because dependent individuals will smoke more per unit time and have more difficulties stopping when they choose to try. ${ }^{56,57}$ Users will, by definition, have no problems stopping if they desire to do so. Thus, few of them will appear in a physician's office asking for help in cessation. The number of these individuals probably has become increasingly smaller since the health risks of smoking have become accepted public knowledge and the panache associated with smoking that existed prior to the first Surgeon General's report on smoking and health ${ }^{58}$ has largely evaporated. According to Spitzer and associates, ${ }^{55}$ true tobacco dependence is characterized by continuous use of tobacco for at least 1 month, with at least one of the following situations: serious attempts to stop or significantly reduce the amount of tobacco use on a permanent basis have been unsuccessful; attempts to stop smoking have led to the development of tobacco withdrawal (craving for tobacco, irritability, anxiety, difficulties in concentrating, restlessness, headache, drowsiness, and/or gastrointestinal disturbances); and/or the person continues to use tobacco despite a serious physical disorder that he or she knows is exacerbated by such use.

\section{Epidemiology}

Having decreased from a high incidence for males of about 55 percent in the early 1960 s and increased from about 24 percent for females during the same period, the current prevalence of smoking in the adult U.S. population appears to be about 32 percent. ${ }^{59-61}$ This means that at least 55 million Americans continue to smoke.

Perhaps the most disturbing epidemiologic trend is continued experimentation with tobacco by about 1 in 5 adolescents. ${ }^{62,63}$ While a slight downward trend in cigarette smoking among adolescents has been observed in the last several years, the use of smokeless tobacco (snuff, chewing tobacco) appears to be on the increase. ${ }^{64-67}$ Given what is known about the natural history of tobacco use, this continued use of tobacco among adolescents portends a significant group of tobacco-dependent individuals who will continue to develop serious tobacco-related illnesses at a high rate.

\section{Natural history}

Tobacco use typically begins in adolescence. The odds of becoming a tobacco user among those who have not started by age 20 are less than 5 percent. ${ }^{68}$ However, 1 of 5 adolescents reports at least occasional use (1 episode/month) of tobacco. People who start smoking in their teens will smoke more heavily than those who start later, will inhale more deeply, and will have greater difficulties stopping. ${ }^{48,56}$

Smokers typically want to stop smoking. Most persons will initially try to stop without professional help. About 77 percent have made at least one serious (that is, professionally assisted) attempt at cessation. ${ }^{1}$ The person who finally succeeds at cessation will have tried an average 6-7 times to stop. ${ }^{69}$ Unfortunately, each failure discourages 10-15 percent from trying again. ${ }^{1}$ Those who do eventually seek help will be heavier smokers with a stronger intensity of nicotine dependence. ${ }^{69}$

\section{Etiology}

The causes of smoking are complex, but current evidence suggests that initiation of the habit is most commonly caused by psychosocial pressures to conform to subcultural peer norms during adolescence. ${ }^{1,68,70-73}$ The desire to conform to perceived peer expectations is generally strong during adolescence. ${ }^{74}$ It is intriguing to note that these psychosocial contingencies are sufficiently powerful to override the ocular, nasal, oral, esophageal, and pulmonary irritation that smokers experience during the initial period of dependence formation. Those adolescents whose parents smoke and are 
permissive about smoking by their children are more likely to develop the habit. ${ }^{75-78}$ And adolescents with friends who smoke and who are lacking in school achievement are also at greater risk to start smoking. ${ }^{79-81}$

By the time local tissue irritation has habituated, the smoker will have begun to display physiologic tobacco dependence. While smoke contains some 4,000 substances, the dependence phenomenon appears to be primarily caused by nicotine. ${ }^{56}$ Withdrawal at this stage, which typically lasts 10 days to 3 weeks, results in a number of subjective (depression, anxiety, irritability, restlessness, intense craving, and decreased concentration) and objective (changes in sleep stage architecture, sweating, gastrointestinal disturbances, decreased heart rate and blood pressure, disturbed time perception, impaired psychomotor performance, and an increase in delta wave electroencephalographic density) symptoms. ${ }^{82-86}$ At this stage smokers will, unknowingly, titrate their habit to maintain a given serum level of nicotine. ${ }^{87-89}$ By this time, smoking has also come to serve a new set of psychosocial coping functions. The patient will smoke more during periods of exposure to acute or long-term psychologic stressors. ${ }^{90-94}$ The mild euphoria experienced some 2-30 seconds after initiating smoking appears to be the subjective correlate of the rapid rise in serum nicotine levels observed in smokers ${ }^{95,96}$ and the event that serves the psychologic need for affective self control in response to such stressors. ${ }^{97}$

\section{Treatment}

\section{General observations}

It is obviously preferable to prevent the onset of smoking as opposed to treating it once established. Effective smoking prevention programs for adolescents are being developed ${ }^{63,81,98-108}$ but these have not yet been widely adopted by school systems.

For example, a program developed by Evans ${ }^{70}$ took 1 hour per day with seventh grade classes, on each of 4 consecutive days, to present, test understanding of, and discuss a 10-minute videotape depicting peer, parental, and media pressure to smoke. Each videotape contained similarly aged children being encouraged to smoke and successfully resisting the pressure. This particular program has been demonstrated ${ }^{109,110}$ to reduce experimentation with tobacco by about half over the course of the 9-month academic year (from 18.3 to 9.6 percent). Its long-term efficacy is unknown at present. The efficacy of this program appears to depend on emphasizing the immediate social con- sequences of smoking (bad taste and smell leading to bad breath, unpleasant kissing, or social ostracism) rather than the long-term health consequences.

While most smokers initially will attempt cessation on their own, the first professional consultation a tobacco-dependent individual will arrange usually is with his/her primary care physician. Many physicians are frustrated by these contacts because they feel unprepared to cope adequately with the problem. A high proportion of these patients will not succeed at cessation (defined as 1 month of abstinence), will relapse following cessation (70-80 percent), or cannot be entirely trusted to be candid when reporting their smoking behavior. ${ }^{111-113}$ It will help the physician faced with these patients to bear in mind that cessation and maintenance is a lifelong process..$^{1,69} \mathrm{Six}$, seven, or more attempts are typical for the patient who eventually succeeds at long-term abstinence. ${ }^{69}$ This long-range perspective hopefully will reduce the physician's frustration about being repeatedly confronted with failures and thus enable him/her to be of greater assistance to the patient. In addition, it may help the physician to know that even very brief discussions with patients about the health risks of smoking and the discomfort of stopping increases the odds of the patient successfully stopping. ${ }^{114-116}$ Brief discussions with general practitioners accompanied by a leaflet and a promise of follow up increased 1-year, patient-reported (but not objectively confirmed) abstinence rates from 10.3 to 19.1 percent. ${ }^{117}$ Unfortunately, this percentage is probably an overestimate of the actual abstinence rate because the self-report data were not validated with urinary or serum measures, and it is known that 10-30 percent of self-reported abstainers misrepresent their smoking status. ${ }^{111-113}$ While this abstinence rate does not approach that typically seen in behavioral treatment programs, it is significantly better than no intervention at all. It should be noted that this study indicates at least 81 percent of smoking patients will not be able to cease usage or will relapse within a year following this kind of minimal help. This high failure rate is probably what discourages many physicians from trying to intervene with smokers.

Characteristics of patients likely to succeed at cessation and maintenance include having nonsmoking friends, ${ }^{118}$ an emotionally healthy relationship with his/her spouse, ${ }^{118}$ supportive friends and family, ${ }^{118-120}$ a history of lengthy abstinence(s) and fewer experiences with relapse, ${ }^{121,122}$ higher socioeconomic status, ${ }^{123}$ good physical health, ${ }^{123}$ 
later onset of smoking, ${ }^{123}$ and spontaneous use of cognitive coping strategies during withdrawal. ${ }^{124}$

\section{Behavior modification}

Behavioral treatment has proved to be highly efficacious in achieving cessation of smoking. Cessation rates of $60-80$ percent for periods of up to 1 month are typically reported, thus accomplishing the task of physiologic withdrawal. ${ }^{56,59}$ But longterm maintenance has been poor in the past, with 70-80 percent of those who accomplish withdrawal relapsing within a year. ${ }^{125-129}$ It has become apparent that smoking cessation must be viewed as a lifelong process if abstinence is to be permanent. This means that efforts must be made to prepare patients to cope with the causes of relapse as well as the causes of failure at withdrawal, which has been neglected in behavioral treatment programs until very recently. ${ }^{130-137}$ The primary cause of failure to achieve cessation appears to be an inability to tolerate the initial period of withdrawal discomfort. ${ }^{1,56,95,96,138-140}$ The primary cause of relapse following successful withdrawal is an inability to cope with periods of elevated psychosocial demand (that is, stress) without resuming usage. ${ }^{90-93,131-137,141-144}$ Patients who have accomplished withdrawal typically report a yen to pick up the habit when confronted with events they find distressing. Behavioral programs attending to relapse prevention have typically reported $40-50$ percent abstinence rates at 6-12 month follow up. ${ }^{145}$

The application of classic (Pavlovian) conditioning principles, using electric shock as the unconditioned aversive stimulus, has demonstrated that smoking is a complex process. ${ }^{146}$ For example, the primary determinant of successful treatment in such regimens was not the application of the shock, but the psychologic health and motivation of the patient to stop. ${ }^{147}$ More sophisticatedand more effective - treatment programs have been designed according to operant conditioning principles that incorporate an accurate understanding of the interpersonal/cognitive/affective processes involved in smoking. ${ }^{125-127}$ Among the useful techniques identified by behavioral research are: identification and avoidance of environments that elicit smoking and the yen to smoke during withdrawal ${ }^{148}$; preparation of the patient for the duration and nature of withdrawal and the likelihood that the impulse to smoke will return during periods of psychosocial stress ${ }^{90-93,141-143,149}$; preparation of others in the patient's environment for his/her irritability/moodiness during withdrawal; con- tracting with the patient for negative contingencies if he/she resumes smoking ${ }^{150-152}$; making available alternative modes of coping at those points in time when the impulse to smoke is particularly intense $^{153,154}$; use of self-administered contingencies using imagery ${ }^{155}$; rapid smoking to produce a tastenausea conditioned association ${ }^{144}$; group treatment in which social cohesiveness is fostered ${ }^{156}$; programmed relapse practice ${ }^{157}$; substitution of other forms of oral stimulation during withdrawal ${ }^{158}$; use of relaxation/hypnosis as a coping technique during withdrawal ${ }^{159,160}$; and minimization of withdrawal symptoms. ${ }^{161}$ In contrast, ineffective techniques have also been identified; these include rapid cessation $^{162}$ and graduated use of filters. ${ }^{163}$

\section{Nicotine-containing chewing gum}

Recently, a nicotine-containing chewing gum has become available as an adjunct to behavioral treatment. Available in 2- and 4-mg. doses in Europe, the FDA has only approved the 2-mg. dose for use in the U.S. To date, the most common side effects with gum use include hiccups (30 percent), nausea (25 percent), dizziness ( 30 percent), sore gums ( 30 percent), and stomachache (40 percent); less common side effects include irritation of the tongue, mouth, and throat, ulceration of the tongue, and flatulence. ${ }^{96,164-166}$ Absolute contraindications to the use of the gum include pregnancy, unstable coronary heart disease, and temporomandibular joint syndrome. Gum use may aggravate coronary heart disease, vasospastic conditions, hypertension, peptic ulcers, diabetes, hyperthyroidism, and esophagitis. ${ }^{167}$ These patients should try behavioral treatment alone before being placed on the gum because of the known pathogenic effects of nicotine for these conditions.

Research regarding the efficacy of the nicotine gum has tried to answer a variety of questions, such as: Is the gum more effective than usual care (physician counseling or behavioral treatment)? Is any positive effect of the gum attributable to the active ingredient (nicotine) or to a placebo response? and How does gum use affect cessation versus maintenance?

Because cessation without maintenance is a Pyrrhic victory with regard to the patient's health, the present summarization (Table 1) and discussion will be limited to studies meeting the following criteria: follow-up periods of at least 10 months; use of total abstinence as the outcome measure; verification of patient self reporting with urinary or 
TABLE 1. SUMMARIZATION OF EFFICACY STUDIES INVOLVING NICOTINE-CONTAINING CHEWING GUM THAT MEET THE METHODOLOGIC CRITERIA STATED IN THE TEXT.*

\begin{tabular}{|c|c|c|c|c|c|c|c|c|}
\hline \multirow[b]{2}{*}{ Authors } & \multicolumn{8}{|c|}{ Form of treatment } \\
\hline & $\begin{array}{l}\text { No } \\
\text { treatment }\end{array}$ & $\begin{array}{l}\text { Gum } \\
\text { alone }\end{array}$ & $\begin{array}{l}\text { Physician } \\
\text { counseling }\end{array}$ & $\begin{array}{l}\text { Gum and } \\
\text { physician } \\
\text { counseling }\end{array}$ & $\begin{array}{l}\text { Placebo and } \\
\text { physician } \\
\text { counseling }\end{array}$ & $\begin{array}{l}\text { Behavioral } \\
\text { treatment }\end{array}$ & $\begin{array}{l}\text { Gum and } \\
\text { behavioral } \\
\text { treatment }\end{array}$ & $\begin{array}{l}\text { Placebo and } \\
\text { behavioral } \\
\text { treatment }\end{array}$ \\
\hline $\begin{array}{l}\text { Russell and } \\
\text { associates }^{139}\end{array}$ & & & & & & & $\begin{array}{l}23 \% \\
(43)\end{array}$ & \\
\hline $\begin{array}{l}\text { Jarvis and } \\
\text { associates }^{164}\end{array}$ & & & & & & & $\begin{array}{l}47 \% \\
(58)\end{array}$ & $\begin{array}{l}21 \% \\
(58)\end{array}$ \\
\hline $\begin{array}{l}\text { Fee and } \\
\text { Stewart }\end{array}$ & & & & & & & $\begin{array}{l}12.7 \% \\
(180)\end{array}$ & $\begin{array}{l}8.7 \% \\
(172)\end{array}$ \\
\hline $\begin{array}{l}\text { Russell and } \\
\text { associates }^{115}\end{array}$ & $3.9 \%$ & $(584)$ & $\begin{array}{l}4.1 \% \\
(675)\end{array}$ & $\begin{array}{l}8.8 \% \\
(679)\end{array}$ & & & & \\
\hline $\begin{array}{l}\text { Schneider and } \\
\text { associates }{ }^{168}\end{array}$ & & $\begin{array}{l}8 \% \\
(13)\end{array}$ & & & & & $\begin{array}{l}30 \% \\
(30)\end{array}$ & $\begin{array}{l}20 \% \\
(30)\end{array}$ \\
\hline $\begin{array}{l}\text { Crofton and } \\
\text { associates }^{169}\end{array}$ & & & $\begin{array}{l}8.5 \% \\
(377)\end{array}$ & $\begin{array}{l}9.8 \% \\
(400)\end{array}$ & $\begin{array}{l}11.4 \% \\
(402)\end{array}$ & & & \\
\hline Fagerström ${ }^{170}$ & $\begin{array}{l}3 \% \\
(27)\end{array}$ & $\begin{array}{l}22 \% \\
(46)\end{array}$ & $\begin{array}{l}15 \% \\
(22)\end{array}$ & $\begin{array}{l}27 \% \\
(50)\end{array}$ & & & & \\
\hline $\begin{array}{l}\text { Jarvik and } \\
\text { Schneider }{ }^{171}\end{array}$ & & & & & & & $\begin{array}{l}27 \% \\
(30)\end{array}$ & $\begin{array}{l}11 \% \\
(18)\end{array}$ \\
\hline $\begin{array}{l}\text { Jamrozik and } \\
\text { associates }{ }^{172}\end{array}$ & & & & $\begin{array}{l}9.9 \% \\
(101)\end{array}$ & $\begin{array}{l}8.1 \% \\
(99)\end{array}$ & & & \\
\hline $\begin{array}{l}\text { Killen and } \\
\text { associates }^{140}\end{array}$ & & $\begin{array}{l}23 \% \\
(22)\end{array}$ & & & & $\begin{array}{l}30 \% \\
(20)\end{array}$ & $\begin{array}{l}50 \% \\
(22)\end{array}$ & \\
\hline Hjalmarson $^{173}$ & & & & & & & $\begin{array}{l}29 \% \\
(106)\end{array}$ & $\begin{array}{l}16 \% \\
(99)\end{array}$ \\
\hline $\begin{array}{l}\text { Marshall } \\
\text { and Raw }{ }^{174}\end{array}$ & & $\begin{array}{l}14 \% \\
(100) \\
\end{array}$ & - & $\begin{array}{l}17 \% \\
(100) \\
\end{array}$ & L & 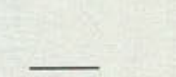 & $\longrightarrow$ & \\
\hline WAA = & $3.8 \%$ & $16.7 \%$ & $5.9 \%$ & $10.5 \%$ & $10.7 \%$ & ID & $25.3 \%$ & $13.5 \%$ \\
\hline
\end{tabular}


serum measures of cotinine, thiocyanate, or carboxyhemaglobin or expired carbon monoxide values; random assignment of patients; and, when appropriate to the purpose of the study, placebo-controlled and double-blinding regarding gum use. ${ }^{115,139,168-179}$ If patients were subgrouped (high versus low nicotine dependence) in a study, the subgroups were averaged to assess treatment form effects. If more than one form of treatment were used in a study (low- versus high-contact physician couseling), the more aggressive of the two treatment regimens (high-contact physician counseling) is classified as "physician counseling," while the less aggressive regimen is classified as "no treatment." Dropouts are included as treatment failures. The data in Table 1 are summarized by weighing the percentage of abstinent patients by the sample size for the respective treatment form and averaging the available data on each of the forms of treatment (gum use alone with minimal or no counseling, physician counseling alone, gum and physician counseling, placebo and physician counseling, behavioral treatment alone, gum and behavioral treatment, placebo and behavioral treatment) and no treatment. No weighted average abstinence is presented if less than two studies contained a given form of treatment regimen. This type of summarization assumes commonalities across diverse forms of physician counseling and behavioral treatment. Nonetheless, it may serve to illustrate the general effectiveness of each form of treatment. No direct test of statistical significance of the summarized data is possible, because variance measures were not provided by most of the studies meeting the inclusion criteria.

As can be seen in Table 1, the average 1-year abstinence rate with gum use alone is 16.7 percent. This appears substantially better than no treatment (3.8 percent) or physician counseling alone (5.9 percent) and, paradoxically, may be better than gum use combined with physician counseling (10.5 percent). But clearly the most effective use of the gum occurs when it is incorporated into some form of behavioral treatment, with 1-year abstinence rates increasing to 25.3 percent. The best designed programs using both behavioral interventions and gum yield 1-year, verified abstinence rates as high as 50 percent. ${ }^{140,164}$

While the effects of solo use of the chewing gum are superior to no treatment and physician counseling, adjunctive use of the gum within traditional behavioral programs appears to enhance the likelihood of the patient tolerating withdrawal and, thus, short-term (approximately 1 month) cessa- tion rates, but not long-term (approximately 1 year) abstinence. This is particularly true for the highly nicotine-dependent individual. ${ }^{171,176,177}$ For example, 6-week follow up in a study ${ }^{140}$ providing nicotine gum (NG), self-regulation training (ST), or both $(\mathrm{NG}+\mathrm{ST})$ to three randomly assigned groups yielded abstinence rates as follows: $\mathrm{NG}=64$ percent; $\mathrm{ST}=55$ percent; and NG $+\mathrm{ST}=86$ percent. For 10.5-month follow up, the abstinence rates were: $\mathrm{NG}=23$ percent; $\mathrm{ST}=30$ percent; and $\mathrm{NG}+\mathrm{ST}=50$ percent. Thus, relapse rates for those patients who had successfully accomplished cessation were: $\mathrm{NG}=64$ percent; $\mathrm{ST}=45$ percent; and $\mathrm{NG}+\mathrm{ST}=42$ percent. Reduction of relapse is almost entirely dependent on the presence of a behavioral treatment regimen. From these results, and a number of other similar studies, it appears that the gum is maximally effective at assisting patients in accomplishing with drawal. ${ }^{115,138,139,164-174,177}$ But long-term maintenance requires cognitive and behavioral changes that will allow the individual to prophylactically recognize and anticipate environments and events that will induce the impulse to smoke, and to cope with these psychosocial stressors without resuming usage. By diminishing the discomfort of withdrawal, and possibly helping patients control the desire to smoke during periods of high psychosocial demand, the gum appears to enhance the efficacy of behavioral treatment in accomplishing cessation. Because short-term cessation offers little or no benefit to the patient's health, and each successive failure at cessation makes another attempt less likely, use of the gum alone without behavioral treatment is generally considered unacceptable. ${ }^{138,167,178-181}$ Appropriate use of the gum requires careful monitoring and instruction. ${ }^{139,} 182$ For example, patients must understand that the gum will not provide the mild euphoria attendant to smoking. ${ }^{95,96}$ Thus, the psychologic need for affective self control served by this euphoria will not be met by gum use. Patients must develop other means (for example, relaxation, exercise, and/or changes in interpersonal style) of coping with such events.

\section{Smoking and the primary care physician}

Possibly the most important contribution the primary care physician can make to the health of his/ her patients is to promote the introduction into the schools of programs developed for preventing the onset of smoking in adolescents. Such programs are not expensive or time consuming. And little can be said against their value vis-á-vis standard classroom topics. Adolescents who are spared depen- 
dence upon tobacco as a result of such programs will increase, on average, both the quantity and quality of their lives and the lives of those who occupy the same environment. Few nobler endeavors can capture the time and energy of the physician. Yet the problem most frequently confronting the primary care physician in the context of his/her practice will continue to be the individual who smokes and wants or needs to stop.

The roles a primary care physician can play in this secondary prevention enterprise include support and encouragement for the patient's efforts. Such support from a trusted physician is demonstrably effective in increasing the likelihood of attempted and successful cessations. ${ }^{114,115,117}$ Prescription and monitoring of gum use are also appropriate activities. ${ }^{138,167}$ While behavioral treatment is probably best conducted by trained mental health professionals ${ }^{183-186}$ the epidemic nature of the smoking problem and the shortage of adequately trained professionals makes this preferred format frequently difficult to realize. ${ }^{187} \mathrm{In}$ our opinion, primary care physicians who undertake serious education and training in the behavioral techniques for smoking diagnosis, cessation, and relapse prevention can conduct behavioral treatment programs for patients who do not have a life-threatening, smoking-related illness. They must, however, take pains to recognize and pretreat patients with psychologic problems that are likely to interfere with smoking treatment (depression, anxiety disorders, periods of elevated life change) and/or are not amenable to group-style treatment (sexual disorders and dysfunctions). Such efforts must not be limited to monthly, or even weekly, 15-minute office visits. ${ }^{185,186,188}$ Extensive evaluation of the circumstances, and concomitant behavioral and subjective responses, preceding periods of desire to smoke must be undertaken in order to accurately understand naturally occuring stress-response relationships, which will continue to influence smoking desires and behaviors during and after withdrawal.

Many physicians may not find behavioral treatment an effective use of their time or feel unprepared to apply behavioral principles within the idiosyncratic circumstances of an individual patient's life. In these cases, cooperative efforts with a psychologist or psychiatrist should be considered.

\section{Summary}

Tobacco use is a major cause of a number of lifethreatening and life-diminishing illnesses. While significant gains have been made over the last two decades in reducing the incidence of tobacco use among adults in this country, continued experimentation among adolescents makes it clear that widespread tobacco use will be with us for a long time to come. Significant gains have been made recently by adjunctive use of nicotine-containing chewing gum within traditional behavioral treatment regimens. The gum enhances success at cessation but is ineffective in improving long-term maintenance. Given the epidemic nature of the problem, the primary care physician must play a major role in the treatment of smoking. In an era of medical cost containment and disease prevention/ health promotion, risk reduction activities such as smoking cessation will likely occupy an increasing proportion of the physician's time. The advocacy of preventive programs directed at adolescents may help some avoid the physical pain, emotional anguish, and spiraling costs of tertiary care for smoking-related diseases.

1. Russell, M.A.H.: Cigarette smoking. Natural history of a dependence disorder. Br J Med Psychol 44:1-16, Mar 71

2. Seffrin, J.R.: Hypocrisy - by default or design? Smoking Health Reporter 2:3, Apr 85

3. Felch, W.C.: Tobacco tomfoolery. Internist 25:19-20, 1984

4. Koop, C.E.: The health consequences of smoking. Cardiovascular disease. Public Health Service, Rockville, Maryland, 1983

5. Bednarzewski, J.: Has withdrawal of tobacco smoking after acute myocardial infarction any effect on late prognosis? Wiadomosci Lekarski 37:569-76, Apr 84

6. Stewart, A.W., et al.: Trends in survival after myocardial infarction in New Zealand, 1974-81. Lancet 2:444-6, 25 Aug 84

7. Cintron, G.B.: After the infarct. What? Cardiovasc Rev Rep 5:665-77, Jul 84

8. Martin, J.L., et al.: Acute coronary vasoconstrictive effects of cigarette smoking in coronary heart disease. Am J Cardiol 54:56-60, 1 Jul 84

9. Davis, M.J.E., et al.: Cigarette smoking and ventricular arrhythmia in coronary heart disease. Am J Cardiol 54:282-5, 1 Aug 84

10. Rosenberg, L., et al:: Myocardial infarction and cigarette smoking in women younger than 50 years of age. JAMA 253:2965-9, May 85

11. Horlick, L., et al.: The effects of education and group discussion in the post myocardial infarction patient. J Psychosom Res 28:485-92, 1984

12. Weintraub, W.S., et al.: Importance of total life consumption of cigarettes as a risk factor for coronary artery disease. Am J Cardiol 55:669-72, 1 Mar 85

13. Johansson, S., et al.: Cessation of smoking after myocardial infarction in women. Effects on mortality and reinfarctions. Am J Epidemiol 121:823-31, Jun 85

14. Rosenberg, L., et al.: The risk of myocardial infarction after quitting smoking in men under 55 years of age. N Engl J Med 313:1511-6, 12 Dec 85 15. Ockene, J.K., et al.: Factors affecting cigarette smoking status in patients with ischemic heart disease. J Chron Dis 38:985-94, 1985

16. Hallstrom, A.P., Cobb, L.A., and Ray, R.: Smoking as a risk factor for recurrence of sudden cardiac arrest. N Engl J Med 314:271-6, 30 Jan 86 17. Petersson, B., Trell, E., and Hood, B.: Premature death and associated risk factors in urban middle-aged men. Am J Med 77:418-26, Sep 84

18. Perkins, J., and Dick, T.B.S.: Smoking and myocardial infarction. Secondary prevention. Postgrad Med J 61:295-300, Apr 85

19. Kannel, W.B., and McGee, D.L.: Epidemiology of sudden death. Insights from the Framingham study. In Sudden cardiac death, edited by M.E. Josephson. F.A. Davis Co., Philadelphia, 1985

20. Ackley, E., and Valentine, S.: Smoking cessation by patients with coronary artery disease. Focus Crit Car 12:50-6, Apr 85 
21. Koop, C.E.: The health consequences of smoking. Cancer. Public Health Service, Rockville, Maryland, 1982

22. Lubin, J.H., et al.: Modifying risk of developing lung cancer by changing habits of cigarette smoking. Br Med J 288:1953-6, 30 Jun 84

23. Lesko, S.M., et al.: Cigarette smoking and the risk of endometrial cancer. N Engl J Med 313:593-6, 5 Sep 85

24. American Cancer Society: Cancer figures and facts. American Cancer Society, Inc., New York, 1984

25. Mastrandrea, V., LaRosa, F., and Cresci, A.: Trends of lung cancer mortality in Italy in relation to consumption of tobacco products. Am J Epidemiol 120:257-64, Aug 84

26. Koop, C.E.: The health consequences of smoking. Chronic obstructive lung disease. Public Health Service, Rockville, Maryland, 1984

27. Christen, A.G., et al.: Effects of nicotine-containing chewing gum on oral soft and hard tissues. A clinical study. Oral Surg Oral Med Oral Pathol 59:37-42, Jan 85

28. Jensen, J., Christiansen, C., and Rodbro, P.: Cigarette smoking, serum estrogens and bone loss during hormone-replacement therapy early after menopause. N Engl J Med 313:973-8, 8 Aug 85

29. Mettinger, K.L., Söderström, C.E., and Neiman, J.: Stroke before 55 years of age at Karolinska Hospital 1973-1977. A study of 399 welldefined cases. Risk indicators and etiological considerations. Acta Neurol Scand 70:415-22, Dec 84

30. Longstreth, W.T., et al.: Risk factors for subarachnoid hemorrhage. Stroke 16:377-85, May-Jun 85

31. Hartz, A.J., et al.: The association of smoking with cardiomyopathy. $\mathrm{N}$ Engl J Med 311:1201-6, 8 Nov 84

32. Forsberg, L., et al.: Impotence, smoking and beta-blocking drugs. Fertil Steril 31:589-91, May 79

33. Virag, R., Bouilly, P., and Frydman, D.: Is impotence an arterial disorder? A study of arterial risk factors in 440 impotent men. Lancet 1:181-4, 26 Jan 85

34. Sontag, S., et al.: Cimetidine, cigarette smoking, and recurrence of duodenal ulcer. N Engl J Med 311:689-93, 13 Sep 84

35. Baird, D.D., and Wilcox, A.J.: Cigarette smoking associated with delayed conception. JAMA 253:2979-83, 24-31 May 85

36. Howe, G., et al.: Effects of age, cigarette smoking, and other factors on fertility. Findings in a large prospective study. Br Med J 290:1697-1700, 8 Jun 85

37. Benson, R.C.: Gynecology and obstetrics. In Current medical diagnosis and treatment, edited by M.A. Krupp and M.J. Chatton. Lange Medical Publications, Los Altos, California, 1980

38. Nieburg, P., Marks, J.S., and McLaren, N.M.: The fetal tobacco syndrome. JAMA 253:2998-9, 24-31 May 85

39. Naeye, R.L., and Peters, E.C.: Mental development of children whose mothers smoked during pregnancy. Obstet Gynecol 64:601-7, Nov 84

40. L'Enfant, C., and Liu, B.M.: (Passive) smokers versus (voluntary) smokers (editorial). N Engl J Med 302:742-3, 27 Mar 80

41. Garland, C., et al.: Effects of passive smoking on ischemic heart disease mortality of nonsmokers. Am J Epidemiol 121:645-50, May 85

42. Sandler, D.P., et al.: Cancer risk in adulthood from early life exposure to parents' smoking. Am J Pub Health 75:487-92, May 85

43. Sandler, D.P., Everson, R.B., and Wilcox, A.J.: Passive smoking in adulthood and cancer risk. Am J Epidemiol 121:37-48, Jan 85

44. Pedreira, F.A., et al.: Involuntary smoking and incidence of respiratory illness during the first year of life. Pediatrics 75:594-7, Mar 85

45. Tager, I.B., et al.: Effect of cigarette smoking on the pulmonary function of children and adolescents. Am Rev Respir Dis 131:752-9, May 85

46. Oborne, D.J.: Cognitive effects of passive smoking. Ergonomics 26:1163-71, Dec 83

47. Said, G., Patois, E., and Lellouch, J.: Infantile colic and parental smoking. Br Med J 289:660, 15 Sep 84

48. Luce, B.R., and Schweitzer, S.O.: Smoking and alcohol abuse. A comparison of their economic consequences. N Engl J Med 298:569-71, 9 Mar 78

49. Fielding, J.E.: Smoking. Health effects and control (1). N Engl J Med 313:491-8, 22 Aug 85

50. Fielding, J.E.: Smoking. Health effects and control (2). N Engl J Med 313:555-61, 29 Aug 85

51. Ockene, J.K., and Camic, P.M.: Public health approaches to cigarette smoking cessation. Ann Behav Med 7:14-8, 1985

52. Koop, C.E.: The campaign against smokeless tobacco. N Engl J Med 314:1042-4, 17 Apr 86

53. Iglehart, J.K.: The campaign against smoking gains momentum. N Engl J Med 314:1059-64, 17 Apr 86
54. Ginzel, K.H.: The underemphasis on smoking in medical education. NY State J Med 85:299-301, Jul 85

55. Spitzer, R.L. (chair): Diagnostic and statistical manual of mental disorders. Ed 3. American Psychiatric Association, Washington, D.C., 1980

56. Russell, M.A.H.: Cigarette smoking. I. Nature and classification. Br Med J 2:330-1, 8 May 71

57. Hughes, J.R.: Identification of the dependent smoker. Validity and clinical utility. Behav Med Abstr 5:202-4, Fall 84

58. United States Public Health Service: Smoking and health. United States Department of Health, Education, and Welfare, Washington, D.C., 1964

59. Matarrazzo, J.D.: Behavioral health's challenge to academic, scientific, and professional psychology. Am Psychol 37:1-14, Jan 82

60. Shopland, D.R., and Brown, C.: Changes in cigarette smoking prevalence in the U.S. 1955 to 1983. Ann Behav Med 7:5-8, 1985

61. Remington, P.L., et al.: Current smoking trends in the United States. The 1981-1983 behavioral risk factor surveys. JAMA 253:2975-8, 24-31 May 85

62. Bower, B.: Teen drug use - except cocaine-falls. Sci News 127:38, Jan 84

63. Flay, B.R.: Adolescent smoking. Onset and prevention. Ann Behav Med 7:9-13, 1985

64. Croft, J.B., et al.: Patterns of cigarette smoking and smokeless tobacco use in adolescents. The Bogalusa Heart Study (abstract). Proc Soc Behav Med 6:24, 1985

65. Gritz, E.R., Ksir, C., and McCarthy, W.J.: Smokeless tobacco use in the United States. Present and future trends. Ann Behav Med 7:24-7, 1985 66. Lichtenstein, E., Severson, H.H., and Friedman, L.S.: Chewing tobacco use by adolescents. Prevalence and relation to cigarette smoking. Addict Behav 9:351-5, 1984

67. Connolly, G.N., et al.: The reemergence of smokeless tobacco. N Engl J Med 314:1020-7, 17 Apr 86

68. McKennell, A.C.: Implication for health education of social influences on smoking. Am J Pub Health 59:1998-2004, Nov 69

69. Schachter, S.: Recidivism and self-cure of smoking and obesity. Am Psychol 37:436-44, Apr 82

70. Evans, R.I.: Smoking in children. Developing a social psychological strategy of deterrance. Prev Med 5:122-7, Mar 76

71. Skinner, W.F., et al.: Social influences and constraints on the initiation and cessation of adolescent tobacco use. J Behav Med 8:353-9, 1985 72. Gilchrist, L.D., et al.: The relationship of cognitive and behavioral skills to adolescent tobacco smoking. J Sch Health 55:132-4, Apr 85

73. Hunter, S.M.. et al.: Friendly persuasion. Identification of friendship cliques and their effect on the adoption/diffusion of tobacco and alcohol behavior. Bogalusa Heart Study. Proc Soc Behav Med 8:95, 1986

74. Erikson, E.H.: Childhood and society. Norton, New York, 1950

75. Hunter, S.M., et al.: Social learning effects on trial and adoption of cigarette smoking in children. The Bogalusa Heart Study. Prev Med 11:29-42, Jan 82

76. Oechsli, F.W., and Seltzer, C.C.: Teenage smoking and antecedent parental characteristics. A prospective study. Pub Health 98:103-8, Mar 84

77. Burchfiel, C.M., et al.: Predicting the initiation of cigarette smoking in Tecumseh, Michigan. Proc Soc Behav Med 7:74-5, 1986

78. Miner, M.H., et al.: Health beliefs and familial smoking patterns. Effects on onset of cigarette smoking among children. Bogalusa Heart Study. Proc Soc Behav Med 7:95-6, 1986

79. Seltzer, C.C., and Oechsli, F.W.: Psychosocial characteristics of adolescent smokers before they started smoking. Evidence of self-selection. A prospective study. J Chron Dis 38:17-26, 1985

80. Salomon, G., Stein, Y., and Eisenberg, S.: Adolescent smokers and nonsmokers. Profiles and their changing structure. Prev Med 13:446-61, Sep 84

81. Santi, S., et al.: A school-based smoking prevention program. Results of the Waterloo Study. Proc Soc Behav Med 7:11-2, 1986

82. Jarvik, M.E.: Biological factors underlying the smoking habit. In Research on smoking behavior, edited by M.E. Jarvik, J.W. Cullen, and E.R. Gritz. National Institute on Drug Abuse, Rockville, Maryland, 1977 83. Pollin, W: The role of the addictive process as a key step in causation of all tobacco-related diseases. JAMA 252:2874-9, 20-30 Nov 84

84. Hughes, J.R., et al.: Effect of nicotine on the tobacco withdrawal syndrome. Psychopharmacology 83:82-7, 1984

85. Hatsukami, D.K., et al.: Tobacco withdrawal symptoms. An experimental analysis. Psychopharmacology 84:231-6, 1984 
86. Stumpfe, K.D.: Tobacco withdrawal symptoms. Munchener Medizinische Wochenschrift 126:731-5, 1984

87. Ashton, H., and Watson, P.W.: Puffing frequency and nicotine intake in cigarette smokers. Br Med J 3:679, 19 Sep 70

88. Ashton, H., Stepney, R.E.G., and Thompson, J.W.: Self-titration by cigarette smokers. Br Med J 2:357-60, 11 Aug 79

89. Ebert, R.V., McNabb, M.E., and Snow, S.L.: Effect of nicotine chewing gum on plasma nicotine levels of cigarette smokers. Clin Pharmacol Ther 35:495-8, Apr 84

90. Ashenberg, Z.S., Morgan, G.D., and Fisher, E.B.: Psychological stress and smoking recidivism. A prospective assessment (abstract). Proc Soc Behav Med 5:19, 1984

91. Ashenberg, Z.S., Morgan, G.D., and Fisher, E.B.: The role of coping with stress in smoking recidivism (abstract). Proc Soc Behav Med 5:26, 1984

92. Benfari, R.C., et al.: Hyperstress and outcomes in a long-term smoking intervention program. Psychosom Med 44:227-35, Jul 82

93. Ockene, J.K., et al.: Relationship of psychosocial factors to smoking behavior change in an intervention program. Prev Med 11:13-28, Jan 82 94. Pomerleau, O.F., et al.: The effect of cigarette smoking on pain and anxiety. Addict Behav 9:265-71, 1984

95. Russell, M.A.H., Feyerabend, C., and Cole, P.V.: Plasma nicotine levels after cigarette smoking and chewing nicotine gum. Br Med J 1:1043-6, 1 May 76

96. McNabb, M.E., Ebert, R.V., and McCusker, K.: Plasma nicotine levels produced by chewing nicotine gum. JAMA 248:865-8, 20 Aug 82

97. Rose, J.E., Ananda, S., and Jarvik, M.E.: Cigarette smoking during anxiety-provoking and monotonous tasks. Addict Behav 8:353-9, 1983

98. Telch, M.J., et al.: Long-term follow-up of a pilot project on smoking prevention with adolescents. J Behav Med 5:1-8, Mar 82

99. Luepker, R.V., et al.: Prevention of cigarette smoking. Three-year followup on an education program for youth. J Behav Med 6:53-62, Mar 83

100. Tell, G.S, et al. Preventing the onset of cigarette smoking in Norwegian adolescents. The Oslo Youth Study. Prev Med 13:256-75, May 84 101. Botvin, G.J., Renick, N.L., and Baker, E.: The effects of scheduling format and booster sessions on a broad-spectrum psychosocial approach to smoking prevention. J Behav Med 6:359-79, Dec 83

102. Telch, M.J., et al.: Social resistance training for smoking prevention. Investigating the effects of videotape delivery with and without same-age peer leader participation. Proc Soc Behav Med 7:74, 1986

103. Dignan, M.B., Block, G.B., and Steckler, A.: Evaluation of the North Carolina Risk Reduction Program for Smoking and Alcohol. J Sch Health 55:103-6, Mar 85

104. Flay, B.R., Ryan, K.B., and Best, J.A.: Are social-psychological smoking prevention programs effective? The Waterloo Study. J Behav Med $8: 37-59$, Mar 85

105. Heimann-Ratain, G., Hanson, M., and Peregoy, S.M.: The role of focus group interviews in designing a smoking prevention program. J Sch Health 55:13-6, Jan 85

106. Killen, J.D.: Prevention of adolescent tobacco smoking. The social pressure resistance training approach. J Child Psychol Psychiatr 26:7-15, Jan 85

107. Schinke, S.P., Gilchrist, L.D., and Snow, W.H.: Skills intervention to prevent cigarette smoking among adolescents. Am J Pub Health 75:665-7, Jun 85

108. Gilchrist, L.D., and Schinke, S.P.: Self-control skills for smoking prevention. Prog Clin Biol Res 156:125-30, 1984

109. Evans, R.I., et al.: Deterring the onset of smoking in children. Knowledge of immediate physiological effects and coping with peer pressure, media pressure and parent modeling. J Appl Soc Psychol 8:126-35, Apr-Jun 78

110. Evans, R.I., et al.: Social modeling films to deter smoking in adolescents. Results of a three-year field investigation. J Appl Psycho 66:399-414, Aug 81

111. Haley, N.J., Axelrad, C.M., and Tilton, K.A.: Validation of self-reported smoking behavior. Biochemical analyses of cotinine and thiocyanate. Am J Pub Health 73:1204-7, Oct 83

112. Wilcox, R.G., Hughes, J., and Roland, J.: Verification of smoking history in patients after infarction using urinary nicotine and cotinine measurements. Br Med J 2:1026-8, 27 Oct 79

113. Hall, S.M., et al.: Blood cotinine levels as indicators of smoking treatment outcome. Clin Pharmacol Therap 35:810-4, Jun 84

114. Pederson, L.L.: Compliance with physician advice to quit smoking. A review of the literature. Prev Med 11:71-84, Jan 82

115. Russell, M.A.H., et al.: Effect of nicotine chewing gum as an adjunct to general practitioner's advice against smoking. Br Med J 287:1782-5, 10 Dec 83

116. Edwards, J.: Effectiveness of general practitioners' advice to smokers. J Royal Coll Gen Pract 34:298-9, 1984

117. Russell, M.A.H., et al.: Effect of general practitioners' advice against smoking. Br Med J 2:231-5, 28 Jul 79

118. Abrams, D.B., Monti, P.M., and Carey, K.B.: Predictors of six-month outcome of behavioral treatment for smoking at the worksite. Proc Soc Behav Med 7:96, 1986

119. Westman, M., Eden, D., and Shirom, A.: Job stress, cigarette smoking and cessation. The conditioning effects of peer support. Soc Sci Med $20: 637-44,1985$

120. Coppotelli, H.C., and Orleans, C.T.: Partner support and other determinants of smoking cessation maintenance among women. J Consult Clin Psychol 53:455-60, Aug 85

121. Coelho, R.J.: Longest prior abstinence and cessation of smoking Psychol Rep 56:468-70, 1985

122. McCarthy, W.J., Ford, J., and Fielding, J.E.: A self-efficacy change model of smoking cessation and abstinence. Proc Soc Behav Med 7:91-2, 1986

123. Zevon, M.A., Cummings, K.M., and Rustum, M.J.: Stop-smoking clinics. Motivational differences between attendees and non-attendees. Proc Soc Behav Med 7:90, 1986

124. Glasgow, R.E., et al.: Quitting smoking. Strategies used and variables associated with success in a stop-smoking contest. J Consult Clin Psychol 53:905-12, Dec 85

125. Evans, R.I., et al.: Current psychological, social and educational programs in control and prevention of smoking. A critical methodological review. In Atherosclerosis reviews, edited by A.M. Gotto, Jr., and R. Paoletti. Raven Press, New York, 1979, vol. 4

126. Best, J.A., and Bloch, M.: Compliance in the control of cigarette smoking. In Compliance in health care, edited by R.B. Haynes, D.W. Taylor, and D.L. Sackett. Johns Hopkins University Press, Baltimore, 1979

127. Leventhal, H., and Cleary, P.D.: The smoking problem. A review of the research and theory in behavioral risk modification. Psychol Bull $88: 370-405$, Sep 80

128. Bernstein, D.A., and McAlister, A.L.: The modification of smoking behavior. Progress and problems. Addict Behav 1:89-102, 1976

129. West, D.W., et al.: Five year follow-up of smoking withdrawal clinic population. Am J Pub Health 67:536-44, Jun 77

130. Hall, R.G., et al.: Two-year efficacy and safety of rapid smoking therapy in patients with cardiac and pulmonary disease. J Consult Clin Psychol 52:574-81, Aug 84

131. Supnick, J.A., and Colletti, G.: Relapse coping and problem solving training following treatment for smoking. Addict Behav 9:401-4, 1984

132. Horwitz, M.B., et al.: Psychosocial mediators of abstinence, relapse, and continued smoking. A one-year followup of a minimal intervention. Addict Behav 10:29-39, 1985

133. Ossip-Klein, D.J., et al.: Determinants of smoking relapse and predictors of outcome. Proc Soc Behav Med 7:90, 1986

134. Pechacek, T.F., et al.: Relapse among self-help quitters. Proc Soc Behav Med 7:93-4, 1986

135. Curry, S., Marlatt, G.A., and Gordon, J.R.: Cognitive factors and relapse following smoking cessation. Proc Soc Behav Med 7:96, 1986

136. O'Connell, K.A., and Fears, B.A.: Overcoming the urge to smoke. Strategies of long-term abstainers and late relapsers. Proc Soc Behav Med 7:98, 1986

137. Shiffman, S.M.: Coping with temptations to smoke. J Consult Clin Psychol 52:261-7, Apr 84

138. Russell, M.A.H., Raw, M., and Jarvis, M.J.: Clinical use of nicotine chewing gum. Br Med J 280:1599-1602, 28 Jun 80

139. Russell, M.A.H., et al.: Effect of nicotine chewing gum on smoking behavior and as an aid to cigarette withdrawal. Br Med J 2:391-3, 14 Aug 76

140. Killen, J.D., Maccoby, N., and Taylor, C.B.: Nicotine gum and selfregulation training in smoking relapse prevention. Behav Therap 15:234-48, Jun 84

141. Condiotte, M.M., and Lichtenstein, E.: Self-efficacy and relapse in smoking cessation programs. J Consult Clin Psychol 49:648-58, Oct 81 142. Marlatt, G.A., and Gordon, J.R.: Determinants of relapse. Implications for the maintenance of behavior change. In Behavioral medicine: Changing health lifestyles, edited by R.O. Davidson and S.M. Davidson. Brunner, Mazel, New York, 1980

143. Shiffman, S.: Relapse following smoking cessation. A situational analysis. J Consult Clin Psychol 50:71-86, Feb 82 
144. Hall, S.M., et al.: Preventing relapse to cigarette smoking by behavioral skill training. J Consult Clin Psychol 52:372-82, Jun 84

145. Kamarck, T.W., and Lichtenstein, E.: Current trends in clinic-based smoking control. Ann Behav Med 7:19-23, 1985

146. Russell, M.A.H.: Effect of electric aversion therapy on cigarette smoking. Br Med J 1:82-6, Jan 70

147. Russell, M.A.H., Armstrong, E., and Patel, U.A. Temporal contiguity in electric aversion therapy for cigarette smoking. Behav Res Therap 14:103-23, 1976

148. Pomerleau, O.F., and Pomerleau, C.S.: Break the smoking habit. Behavioral Medicine Press, West Hartford, Connecticut, 1977

149. Kowalski, P.A.: After your client quits smoking. Hospital pressure vs. self-motivation. Home Healthcare Nurse 3:27-9, 1985

150. Paxton, R.: Prolonging the effects of deposit contracts with smokers Behav Res Therap 21:425-33, 1983

151. Telch, M.J., et al.: Self-help strategies for smoking cessation. An examination of correspondence course and monetary incentive ap proaches. Proc Soc Behav Med 7:99-100, 1986

152. Kasseye, W.W.: Assessment of the impact of monetary incentives upon smoking behavior. J Drug Ed 14:109-18, 1984

153. Ossip-Klein, D.J., Shapiro, R.M., and Stiggins, J.: Freedom line. A relapse prevention hotline for ex-smokers (abstract). Behav Med Update $6: 15,1984$

154. Corty, E., and McFall, R.M.: Response prevention in the treatment of cigarette smoking. Addict Behav 9:405-8, 1984

155. Berecz, J.: Modification of smoking behavior through self-administered punishment of imagined behavior. A new approach to aversion therapy. J Consult Clin Psychol 38:244-50, 1972

156. Etringer, B.D., Gregory, V.R., and Lando, H.A.: Influence of group cohesion on the behavioral treatment of smoking. J Consult Clin Psychol 52:1080-6, Dec 84

157. Hill, R.D., Johnson, D.J., and Maccoby, N.: Prescribing relapse as a relapse prevention training aid for the maintenance of nonsmoking treatment gains. Proc Soc Behav Med 7:97, 1986

158. Rabkin, S.: Relationship between weight change and the reduction of cessation of cigarette smoking. Int J Obes 8:665-73, 1984

159. Ryde, D.: Hypnotherapy and cigarette smoking. Practitioner 229:29-31, Jan 85

160. Agee, L.L.: Treatment procedures using hypnosis in smoking cessation programs. A review of the literature. J Am Soc Psychosom Dent Med $30: 111-26,1983$

161. Berecz, J.M.: Superiority of low-contrast smoking cessation method. Addict Behav 9:273-8, 1984

162. Schlegel, R.P., et al.: Update on the delayed effects of the "Five day plan to stop smoking." Prev Med 13:320-2, May 84

163. Hymowitz, N., Lasser, N.L., and Safirstein, B.H.: Effects of graduated external filters on smoking cessation. Prev Med 11:85-95, Jan 82

164. Jarvis, M.J., et al.: Randomised controlled trial of nicotine chewing gum. Br Med J 285:537-40, 21 Aug 82

165. Raw, M., et al.: Comparison of nicotine chewing gum and psychological treatments for dependent smokers. Br Med J 280:480-2, 16 Aug 80

166. Fee, W.M., and Stewart, M.J.: A controlled trial of nicotine chewing gum in a smoking withdrawal clinic. Practitioner 226:148-51, Jan 82

167. Hughes, J.R., and Miller, S.A.: Nicotine gum to help stop smoking. JAMA 252:2855-8, 23-30 Nov 84

168. Schneider, N.G., et al.: Nicotine gum in smoking cessation. A placebo-controlled, double-blind trial. Addict Behav 8:253-61, 1983

169. Crofton, J., et al.: Comparison of four methods of smoking withdrawal in patients with smoking related diseases. Br Med J 286:595-7, 19 Feb 83

170. Fagerström, K.O.: Effects of nicotine chewing gum and followup appointments in physician-based smoking cessation programs. Proc Soc Behav Med 5:12, 1984
171. Jarvik, M.E., and Schneider, N.G.: Degree of addiction and effectiveness of nicotine gum therapy for smoking. Am J Psychiatr 141:790-1, Jun 84

172. Jamrozik, K., et al.: Placebo-controlled trial of nicotine chewing gum in general practice. Br Med J 289:794-7, 29 Sep 84

173. Hjalmarson, A.I.M.: Effect of nicotine chewing gum in smoking cessation. A randomized, placebo-controlled, double-blind study. JAMA 252:2835-8, 23-30 Nov 84

174. Marshall, A., and Raw, M.: Nicotine chewing gum in general practice. Effect of follow-up appointments. Br Med J 290:1397-8, 11 May 85 175. Fagerström, K.O.: A comparison of psychological and pharmacological treatment in smoking cessation. J Behav Med 5:343-50, Sep 82

176. Hughes, J.R., et al: Consistency of the tobacco withdrawal syn drome. Addict Behav 9:409-12, 1984

177. Bäckström, I., et al.: Primary treatment of smoking dependence. Nicotine chewing gum is more effective than consultation alone for quitting smoking in tobacco dependence. Lakartidningen 82:1967-70,22 May

178. Nicotine chewing gum. Lancet $1: 320-1,9$ Feb 85

179. Raw, M.: Does nicotine chewing gum work? Br Med J 290:1231-2, 27 Apr 85

180. Ludwig, L.: Smoking withdrawal with Nicorette. Therapiewoche $35: 747,1985$

181. Clavel, F., and Benhamou, S.: To the editor. Br Med J 289:1308, 17 Nov 84

182. Russell, M.A.H.: Nicotine intake and its regulation. J Psychosom Res 24:253-64, 1980

183. Smith, M.L., Glass, G.V., and Miller, T.I.: The benefits of psychotherapy. Johns Hopkins University Press, Baltimore, 1980

184. Parloff, M.B., Waskow, I.E., and Wolfe, B.E.: Research on therapist variables in relation to process and outcome. In Handbook of psychotherapy and behavior change: An empirical analysis, edited by S.L. Garfield and A.E. Bergin. John Wiley \& Sons, New York, 1978

185. Richmond, R.L., and Webster, I.W.: A smoking cessation programme for use in general practice. Med J Aust 142:190-4, 4 Feb 85

186. McIntyre, E.L., et al.: Family physicians and smoking cessation. A comparison of usual care and treatment provided by trained physicians. Proc Soc Behav Med 7:98-9, 1986

187. Chapman, S.: Stop-smoking clinics. A case for their abandonment. Lancet 1:918-20, 20 Apr 85

188. Glasgow, R.E., Schafer, L., and O'Neill, H.K.: Self-help books and amount of therapist contact in smoking cessation programs. J Consult Clin Psychol 49:659-67, Oct 81

Accepted for publication in June 1986. Updating, as necessary, has been done by the authors.

Dr. Ketterer is assistant professor of behavioral sciences, and research scientist at the Center for Behavioral Medicine, at the Oklahoma College of Osteopathic Medicine and Surgery, Tulsa, Oklahoma. Dr. Pickering is clinical professor of internal medicine at OCOMS, and Chairman of the Division of Cardiology at Oklahoma Osteopathic Hospital, Tulsa. Dr. Stoever is clinical professor of internal medicine at OCOMS, and member of the Division of Cardiology at $\mathrm{OOH}$. Dr. Wansley is associate professor of behavioral sciences, and Director, Center for $\mathrm{Be}$ havioral Medicine at OCOMS.

Dr. Ketterer, Center for Behavioral Medicine, 2345 Southwest Boulevard, Tulsa, Oklahoma 74107. 